member of the Colour Group of the Physical Society. Overlapping with his work on colorimetry he has made a number of fundamental studies of the physical chemistry of dyeing. His text-book, "The Physical Chemistry of Dyeing", is now in its second edition, and moves are afoot to translate it into German and Japanese. In 1942 Dr. Vickerstaff was awarded the Research Medal of the Society of Dyers and Colourists as senior author of the paper "The Dyeing of Acetate Rayon with Dispersed Dyes". He was appointed an assistant chief colourist of the Dyestuffs Division in 1949.

\section{Colleges of Advanced Technology}

AN extensive building programme, to start next year, in connexion with technical studies in the universities, estimated to cost about $£ 4,500,000$, was announced during a debate on technical education by Mr. R. A. Butler, Lord Privy Seal, in the House of Commons on June 21. The new buildings are to be dedicated not only to engineering and branches of technology, but also to basic sciences, especially physics and chemistry. The sum announced represents only the contribution of the Exchequer, and does not include other sums which might be contributed by industry or by the universities themselves. These colleges are in future to be designated colleges of advanced technology, and conditions for such designation were circulated on June 21 by Sir David Eccles, Minister of Education, to local authorities. The circular outlines the present organization of technical colleges, and suggests how each kind of college can best contribute to the Government's five-year plan for technical education. Regional co-ordination is essential to the success of this policy, and the Minister asks the local education authorities to co-operate fully with one another. He considers it important that the smaller technical colleges should develop as speedily as possible into colleges of technology.

In the House of Commons on June 21, the Minister named those colleges which will be recognized as advanced colleges of technology. They are : Birmingham College of Technology, Bradford Technical College, Cardiff College of Technology and Commerce, Loughborough College of Technology, The Royal Technical College, Salford, The Battersea Polytechnic, London, The Chelsea Polytechnic, London, The Northampton Polytechnic, London. Some of these colleges do not fulfil the necessary conditions at present, but it is hoped that they will do so in the near future. Among the conditions for designation as a college of advanced technology are strong direct representation of industry, besides representatives of local education authorities, universities and professional technological interests. Teaching conditions must approximate to those of equivalent standard at universitics, and the staff must have opportunities for research and consulting work. The Minister lays considerable stress on the provision of residential accommodation. 'The circular which the Minister has sent to local authorities also describes the three kinds of existing technological colleges, referring to them as local, area and regional colleges.

\section{Frederick D. Edwards Trust for Financial Help for} Technical Students

MR. F. D. EDWARDS, founder and managing director of Edwards High Vacuum, Ltd., has recently formed the Frederick D. Edwards Scholarship Trust, the purpose of which is to give financial aid to tech- nical students pursuing or intending to pursue a course of training in science and technology. The capital of the Trust is $£ 12,000$, and Mr. Edwards has stipulated that the whole of this and its associated income must be spent within ten years. Otherwise, the trustees have a completely free hand to dispose of the money as scholarships, bursaries, prizes, smallscale grants, or in any other way they think fit. Although three institutions are specifically mentioned in the Trust deed-the Northampton Polytechnic, the National College of Instrument Technology and the Crawley Technical College-a student at any institution "giving training courses or facilities for research in any branch of science or technology" is eligible. Inquiries about the Trust and applications for grants should be made through college principals to either of the two trustees: Mr. F. S. B. Murrells (director and secretary of Edwards High Vacuum, Ltd.), at Tresco, Nevill Court, Tunbridge Wells, Kent ; and Mr. A. J. Philpot (retiring director of the British Scientific Instrument Research Association), at Cranley, Bressey Grove, London, E.18.

\section{Rain-making in Tanganyika}

IN a written answer in the House of Commons on May 31, Mr. Lennox-Boyd, Secretary of State for the Colonies, said that because of partial failure of the seasonal rains, the level of the reservoir at the Kazima Dam, which provides Tabora, the railway junction and administrative centre in the Western Province of Tanganyika, was dangerously low at the end of March. A new 'cloud-seeding' technique, involving the use of 2 -in. naval rockets, modified to incorporate particles of sea salt, which had been evolved by the East African Meteorological Department in conjunction with the Admiralty and the Ministry of Supply, was accordingly tried out, and thirty-seven such rockets were fired between April 12 and May 2. Under the conditions prevailing, the best results were obtained when the rockets burst at about 3,000 ft., and 1.5 miles downwind of the catchment area of the Kazima Dam. The results are still being studied, but there was definite evidence that under suitable conditions cloud-seeding produces rain. A significant feature of the experiments was the repeated occurrence of rain over the catchment area some 12 minutes after seeding, and at the end of the experiments the level of the reservoir had risen by $2 \cdot 5$ inches, despite a daily consumption of 250,000 gallons and a high loss through evaporation. Rainfall in the catchment area during April was about one to one and a half inches higher than that measurod at stations near but outside the catch. ment area.

\section{The Houldsworth School of Applied Science, Leeds}

THe Council of the University of Leeds has approved a re-organization of the Department of Coal Gas and Fuel Industries with Metallurgy and Chemical Engineering. Under this re-organization the present Department will be replaced by a School, to be called "The Houldsworth School of Applied Science". Sir Hubert Houldsworth, the late prochancellor of the University, had been for some years a member of the staff of this Department, and through his work as fuel controller and with the National Coal Board was very familiar with its activities. The Houldsworth School of Applied Science will be constituted of three Departments : Gas Engineering and General Fuel Science with Ceramics, directed -by the Livesey professor, Prof. 